\title{
A proposal for including nomophobia in the new DSM-V
}

Nicola Luigi Bragazzi ${ }^{1,2}$ Giovanni Del Puente ${ }^{2}$

'School of Public Health, Department of Health Sciences (DISSAL), University of Genoa, Genoa, Italy; ${ }^{2}$ DINOGMI, Department of Neuroscience, Rehabilitation, Ophthalmology, Genetics, Maternal and Child Health, Section of Psychiatry, University of Genoa, Genoa, Italy
Correspondence: Nicola Luigi Bragazzi School of Public Health, Department of Health Sciences (DISSAL), University of Genoa, Via Antonio Pastore I, 16132 Genoa, Italy

Tel +39 0103537664

Fax +390103537669

Email robertobragazzi@gmail.com
This article was published in the following Dove Press journal:

Psychology Research and Behavior Management

16 May 2014

Number of times this article has been viewed
Abstract: The Diagnostic and Statistical Manual of Mental Disorders (DSM) is considered to be the gold standard manual for assessing the psychiatric diseases and is currently in its fourth version (DSM-IV), while a fifth (DSM-V) has just been released in May 2013. The DSM-V Anxiety Work Group has put forward recommendations to modify the criteria for diagnosing specific phobias. In this manuscript, we propose to consider the inclusion of nomophobia in the DSM-V, and we make a comprehensive overview of the existing literature, discussing the clinical relevance of this pathology, its epidemiological features, the available psychometric scales, and the proposed treatment. Even though nomophobia has not been included in the DSM-V, much more attention is paid to the psychopathological effects of the new media, and the interest in this topic will increase in the near future, together with the attention and caution not to hypercodify as pathological normal behaviors.

Keywords: behavioral dependence, mobile phone, social phobia, specific phobia

\section{Introduction}

The Diagnostic and Statistical Manual of Mental Disorders (DSM, currently in its fourth version, DSM-IV-TR $)^{1}$ represents the standard reference manual for the assessment, diagnosis, and treatment of neuropsychiatric diseases, and since its first version has paralleled the increasing knowledge about brain and psychopathologies as well as the introduction of new diagnostic criteria, adapting its assessment tools accordingly. A feature of the DSM is thus its historicity and its willingness to stay abreast of the latest developments and hypotheses of the changing times. ${ }^{2}$

In the present article, we make a proposal for modifying the section devoted to phobias and potentially including new clinically relevant pathologies.

According to the DSM, a specific phobia is an anxiety disorder that represents unreasonable and irrational fear prompted by a specific stimulus (an object or a situation). Initially termed as "simple phobia" in DSM-III and DSM-III-TR, the name was later changed to "specific phobia," beginning with the DSM-IV version, and at that time, five types of specific phobia were included: blood/injection/injury (B-I-I), animal, natural environment, situational, and other.

An animal type phobia is cued by animals (zoophobia, and for wild animal agrizoophobia) or insects (such as spiders - arachnophobia, snakes - ophidiophobia, rats, and mice - musophobia), while a natural environment type phobia is cued by an object in the natural environment, such as heights (acrophobia), storms, lightning, thunder (brontophobia, keraunophobia, or tonitrophobia, or astraphobia), water (acquaphobia), or the dark (nyctophobia). A B-I-I type phobia is prompted by 
seeing blood (hemophobia) injury, or receiving an injection (trypanophobia), while a situational type phobia is prompted by specific situations such as traveling and driving (hodophobia), tunnels, bridges (gephyrophobia), enclosed places (claustrophobia), or flying (pteromerhanophobia, known also as aerophobia, aviatophobia, or aviophobia). The "other" type phobia is cued by other stimuli, such as loud noises and costumed characters as well as situations that could result in getting ill, choking, or vomiting.

Social phobia disorder is described as an anxiety disorder of chronic evolution and prognosis. It is characterized by intense and marked anxiety in social situations that involve interpersonal contact and interactions, public performance, or both, which can cause extreme anxiety or acute interference in an individual's daily life. The DSM-IV underlines that in order for a formal assessment to be made; the disorder should result in significant interference in at least one important area of the individual's life (such as work, social life, school/ academic activities, or leisure).

Currently these diagnostic criteria are under review, and new recommendations to ameliorate the definition have been put forward by the DSM-V Anxiety Work Group. ${ }^{3}$

Moreover, new phobias are emerging, related to contemporary society and the new challenges continuously faced in the daily routine, such as the so-called technophobias, ${ }^{4}$ which represent a sense of discomfort toward technologies, especially the emerging and advanced ones, cyberphobia, and computerphobia. ${ }^{5}$ Since its first introduction in $1983,{ }^{5}$ the mobile phone has seen an incredible world-wide diffusion, representing today a mainstream and pervasive technology and an important part of our technoculture. ${ }^{6,7}$

The increasing utilization and penetration of new technological devices and virtual communication involving personal computers and tablets - the so-called computer-mediated communication - and mobile phones (such as smartphones) are causing changes in individuals' daily habits and behaviors, as well as in identity and in the common ways of perceiving reality, ${ }^{8}$ creating personal languages and jargon, ${ }^{9}$ and establishing a virtual arena, termed "global virtual community" by Rheingold ${ }^{10}$ and "space of flows" by Castells. ${ }^{11}$ New media are characterized by a dual and ambivalent nature. They can have some benefits and positive aspects; for example, they facilitate exchange of information and communication, they enable people to overcome barriers like spatial proximity and immobility, to go beyond and to blur the conventional geographical boundaries, ${ }^{12,13}$ to mobilize a high number of actors, communication partners, and resources, to maximize the number of transactions, and to be engaged in different interactions and contexts. To a certain extent, it is not an exaggeration to say that using new technologies is a cognitive challenging task that calls upon adequate data processing, willingness to change and accept new devices, and adequate traits of personality such as technology enthusiasm, and readiness. But these new technologies, characterized by the absence of a face-to-face communication, can also interfere with social interactions, causing disturbed behaviors and bad feelings, leading to social isolation, a certain degree of alienation, economic/financial problems (larger debts incurred by the young people), ${ }^{14}$ and both physical and psychological pathologies: damages related to electromagnetic field radiation, ${ }^{15-19}$ car accidents, ${ }^{20-22}$ distress linked to the fear of not being able to use new technological devices (the so-called techno-stress linked to the technological divide or technological gap). ${ }^{23-25}$

In his pioneering work on Internet dependence and over-connection syndrome, Hoffman conceptualizes the paradoxical duality of new media usage, showing that in the short-term, the usage of new media implies more benefits than drawbacks, while in the long-term, it calls for the activation of mechanisms and processes easily leading to addictive and impulsive behaviors.

\section{Discussion}

The disorder termed nomophobia (a portmanteau for "no mobile phone" and phobia) ${ }^{26}$ or mobile phone addiction, ${ }^{27-30}$ is a result of the development of new technologies that enable virtual communication. Nomophobia is considered a disorder of the contemporary digital and virtual society and refers to discomfort, anxiety, nervousness or anguish caused by being out of contact with a mobile phone or computer. Generally speaking, it is the pathological fear of remaining out of touch with technology.

Varied and different are the clinical characteristics of nomophobia: the technological device can be used in an impulsive way ${ }^{31}$ as a protective shell, shield, as a transitional object, ${ }^{32}$ or as a means for avoiding social communication (the so-called "new technologies paradox"): ${ }^{33}$

- To use regularly a mobile phone and to spend considerable time on it, to have one or more devices, to always carry a charger with oneself;

- To feel anxious and nervous at the thought of losing one's own handset or when the mobile phone is not available nearby or is misplaced or cannot be used because of lack of network coverage, flattened battery, and/or lack of credit, and try to avoid as much as possible the places and the situations in which the use of the device is banned (such as public transit, restaurants, theaters, and airports); 
- To look at the phone's screen to see whether messages or calls have been received (a habit referred to by David Laramie as "ringxiety" - a portmanteau for ringer and anxiety);

- To keep the mobile phone always switched on (24 hours a day), to sleep with the mobile device in bed;

- To have few social face-to-face interactions with humans which would lead to anxiety and stress; to prefer to communicate using the new technologies;

- To incur debts or great expense from using the mobile phone.

Ringxiety can assume sometimes intriguing and particular clinical forms of presentation, from the sensation of hearing "phantom ring tones" or "false mobile sounds" or confusing the sound of a cell phone ringing with a sound similar to it to the knee-jerk reaction to search for one's own mobile after hearing or presuming to have heard a ring tone.

\section{Epidemiological characteristics}

According to a survey performed by Stewart Fox-Mills, more than 13 million British people suffer from nomophobia, about $53 \%$ of mobile users (48\% women, $58 \%$ men) (http://www. dailymail.co.uk/news/article-550610/Nomophobia-fearmobile-phone-contact--plague-24-7-age.html). According to a recent survey carried out by SecurEnvoy, women are more worried about losing their mobile devices $(70 \%)$ than are men $(61 \%)$. However, in 2008 , the trend was exactly the opposite with men more likely to suffer from this fear (probably because men are $11 \%$ more likely to have two mobile phones than women). Youngsters and adolescents are more likely to experience nomophobia; 77\% have reported having anxiety and worries about being without their phone, followed by the 25-34-year age group and those over 55 years. Other surveys carried out independently have found similar results, while the Helsinki Institute for Information Technology has found that, on average, people check their phones 34 times a day.

Moreover, many other surveys performed in different countries and cultures - from the USA to India, ${ }^{34}$ from Europe (Spain, Poland, and Finland, for example) ) $^{35-37}$ to $\mathrm{Japan}^{38}$ have confirmed these findings and shown that nomophobia is universally widespread and present. Nomophobia has been described by Indian psychiatrists, who found a threefold increase in psychopathology related to problematic mobile use in the last few years. In addition, different clinical cases have been reported in the USA and in Europe.

\section{Psychological predictors}

Finding psychological predictors has great clinical relevance, since this knowledge could be exploited for screening and for both diagnosis and prognosis. Bianchi and Phillips ${ }^{42}$ have found that psychological predictors of problematic mobile use may be: younger age, self-negative views, low esteem and self-efficacy, a dysregulated arousal (such as in high extroversion or in introversion). Impulsivity, a sense of urgency, and sensation seeking could be also related to mobile phone overuse.

\section{Comorbidity}

Like other psychiatric diseases, an important issue of nomophobia is comorbidity: some scholars talk about a double diagnosis, since often pathologies tend to cluster together, like anxiety and panic disorder, other forms of phobia (and in particular social phobia or social phobia disorder), obsessive-compulsive disorder, eating disorders, depression and dysthymia, alcohol and drug addiction, as well as other behavioral addiction disorders (including mobile and/or Internet dependence, gambling, online gaming, compulsive shopping, and sexual behaviors) and personality disorders (borderline, antisocial, and avoiding, above all). ${ }^{39}$ All these pathologies should also be considered in the differential diagnosis, together with atypical depression and psychosis. In these cases, nomophobia may act as a proxy for a more serious psychiatric disorder.

\section{Psychometric scales}

Even though the topic is very recent, there are some validated psychometric scales, such as Questionnaire of Dependence of Mobile Phone/Test of Mobile Phone Dependence (QDMP/ TMPD), ${ }^{40,41}$ Problematic Mobile Phone Use Questionnaire (PMPUQ), Perceived Dependence on the Mobile Phone (PDMP), ${ }^{33}$ Mobile Phone Problem Use Scale (MPPUS), ${ }^{42}$ Problematic Mobile Phone Use Scale (PMPUS), ${ }^{43}$ Escala breve para evaluar el Abuso de Móvil (EBAM), ${ }^{44}$ Cuestionario de Experiencias Relacionadas con el Móvil/Questionnaire of Experiences Related to the Mobile Phone (CERM/ QERMP), ${ }^{44}$ the Scale of Self-perception of Text-message Dependence (STDS), ${ }^{45}$ Mobile Phone Dependence Questionnaire (MPDQ) ${ }^{46}$ Mobile Addiction Test (MAT),${ }^{47}$ Mobile Phone Addiction Index (MPAI), ${ }^{48}$ Cell-Phone Over-use Scale (COS), ${ }^{49}$ Escala de Medición del Uso Problemático del Móvil (EMUPM), ${ }^{50}$ Excessive Cellular Phone Use Survey (ECPUS), ${ }^{51}$ Text Messaging Gratification Scale (TMG), ${ }^{52}$ and the Mobile Phone Involvement Questionnaire (MPIQ). ${ }^{53}$

QDMP/TMPD has 38 Likert items and a reliability coefficient in the range of $0.85-0.91$. The last version of TMPD was made up of initially 101 items, later reduced to 46 items after the pilot study. The first 18 items were answered on a Likert-type scale ranging from 0 (never) to 4 (frequently). The 28 remaining items asked respondents to use a Likert-type 
scale ranging from 0 (completely disagree) to 4 (completely agree) to respond to a set of statements. Six inverse items were included to control for the acquiescence effect. It has been validated against a sample consisting of 2,833 adolescents between 12 and 18 years of age.

MPPUS is made up of 27 Likert items, has been validated against the MMPI-2 (Minnesota Multiphasic Personality Inventory-2) Addiction Scale, ${ }^{54}$ and has proven to be a reliable self-report instrument, having a Cronbach's alpha coefficient $>0.90$ in all the subscales. MPDQ has 20 Likert questions with Cronbach's alpha coefficient of 0.86 . STDS has 15 Likert items, while MPIQ is made up of 8 questions and has got a Cronbach's alpha coefficient of 0.80 . MPAI has 17 Likert items and a coefficient $>0.90$ in all the subscales. COS, consisting of 23 items, has shown a self-consistence of 0.87 .

PMPUQ consists of 30 questions and a dichotomous one (PDMP), with a good reliability coefficient in the $0.65-0.85$ range. MAT has a questionnaire of 10 Likert items, TMG has 47 questions and a reliability coefficient of 0.86 , while EMUPM has 9 Likert items and a coefficient of 0.80 .

Moreover, models of psychological predictors of an impulsive use of mobile devices are also available. ${ }^{55-61}$ The most important psychological predictors are: personality, emotional intelligence (self-regulation of affective status), social skills, adjustment abilities, self-esteem, smoking, alcohol and drug consumption, other psychopathologies in comorbidity, besides the gender and the socioeconomic status.

\section{Treatment}

Since nomophobia is a relatively new concept, there are a limited number of scholarly accepted and empirical treatment methods for it. The proposed treatments primarily consist of a combination of psychotherapy and some pharmacological interventions.

However, cognitive-behavioral psychotherapy has been suggested as an effective treatment for nomophobia, even though randomized trials are currently lacking. Cognitivebehavioral psychotherapy is a brief therapy that includes structured sessions and specific objectives. Its systematic practice is based on explicit goals and tasks; both the patient and the therapist have active roles. The intention is to link catastrophic interpretations of events and to condition the patient's fears, sensory sensations, and avoidance behaviors. Patients are taught distraction strategies and are strongly encouraged to have face-to-face conversations and relationships. Reducing time spent with a mobile phone, online connections, doing some sport and breathing deeply may all be ways of coping. From a behavioral point of view, patients undergo controlled mobile deprivation.

A "reality approach" is also highly recommended, asking the patient to focus on his/her own behaviors, also using motivational interviewing. Diaries in which participants can record their mobile phone use each day have also been proposed. Psychotherapy can be complemented in the most severe cases by neuropsychopharmacology, and suggested drugs vary from benzodiazepines to antidepressants at the usual dosage. ${ }^{60}$

King et $\mathrm{al}^{27}$ successfully treated a patient suffering from nomophobia with tranylcypromine $20 \mathrm{mg}$ /day (gradually increased up to $40 \mathrm{mg} /$ day) plus clonazepam $0.5 \mathrm{mg}$ /day. Later, this therapy was replaced by clonazepam $1 \mathrm{mg} /$ day alone and administered for 2 months.

\section{Conclusion}

The introduction of mobile phones and new technologies has shaped our daily life, with both positive and negative aspects. It is undeniable that technology through new social media, social network sites, social informatics, and "social software" (an expression coined by Clay Shirky) ${ }^{61}$ enables us to perform our job more quickly and with efficiency, and it is also true that mobile phone-based interventions are a useful medical aid. ${ }^{62-64}$ On the other hand, mobile devices can have a dangerous impact on human health. ${ }^{65}$ Further research is needed, above all academic and scholarly studies, to investigate more in depth the psychological aspects of nomophobia and to provide a standardized and operational definition of it. Inclusion of nomophobia in the DSM-V could be a useful opportunity for providing clinicians with a useful tool, fostering advancements in the field. However, caution should be paid in avoiding tendencies such as nosologomania ${ }^{66-68}$ and psychiatric categories abuse in hypercodifying modern behaviors as pathological. On the other hand, some questions remain open, such as the issues of the double diagnosis and the comorbidities issue. Since the link between new technologies and their psychopathological impact is still unclear, further research in the field is needed.

\section{Disclosure}

The authors declare they have no conflict of interests.

\section{References}

1. American Psychiatric Association. Diagnostic and Statistical Manual of Mental Disorders, Fourth Edition, Text Revision (DSM-IV-TR). Washington, DC: American Psychiatric Association; 2000.

2. Kawa S, Giordano J. A brief historicity of the Diagnostic and Statistical Manual of Mental Disorders: issues and implications for the future of psychiatric canon and practice. Philos Ethics Humanit Med. 2012;7:2. 
3. LeBeau RT, Glenn D, Liao B, et al. Specific phobia: a review of DSM-IV specific phobia and preliminary recommendations for DSM-V. Depress Anxiety. 2010;27:148-167.

4. Brosnan M. Technophobia: The Psychological Impact of Information Technology. London: Routledge; 1998.

5. Australian Mobile Telecommunications Association. AMTA 2003 Annual Report. Canberra, Australian Capital Territory: Australian Mobile Telecommunications Association; 2003.

6. Katz JE, Aakhus M. Perpetual Contact: Mobile Communication, Private Talk, Public Performance. Cambridge: Cambridge University Press; 2002.

7. Postman N. Technopoly: The Surrender of Culture to Technology. New York: Vintage Books; 1992.

8. Handy C. Waiting for the mountain to move: and other reflections on life. London: Arrow; 1992.

9. Green J. Language: intrtxtlty. Crit $Q$. 2007;49:124-128.

10. Rheingold, H. (1993). The Virtual Community: Homesteading on the Electronic Frontier. New York: Harper Perennial.

11. Castells M. The Rise of the Network Society. 2nd ed. Oxford: Blackwell; 2001

12. Sheller M. Mobile publics: beyond the network perspective. Environ Plan D. 2004;22(1):39-52.

13. Schwanen T, Kwan MP. The Internet, mobile phone and space-time constraints. Geoforum. 2008;39(3):1362-1377.

14. Funston A, MacNeill K. Mobile Matters: Young People and Mobile Phones. Melbourne: Communication Law Centre; 1999.

15. Leszczynski D, Joenväärä S, Reivinen J, Kuokka R. Non-thermal activation of the hsp27/p38MAPK stress pathway by mobile phone radiation in human endothelial cells: molecular mechanism for cancer- and blood-brain barrier-related effects. Differentiation. 2002;70:120-129.

16. Hyland G. Physics and biology of mobile telephony. Lancet. 2000;356:1833-1836.

17. Hepworth SJ, Schoemaker MJ, Muir KR, Swerdlow AJ, van Tongeren MJA, McKinney PA. Mobile phone use and risk of glioma in adults: case-control study. BMJ. 2006;332(7546):883-887.

18. Röösli M, Frei P, Mohler E, Hug K. Systematic review on the health effects of exposure to radiofrequency electromagnetic fields from mobile phone base stations. Bull World Health Organ. 2010;88(12): 887-896F.

19. Samkange-Zeeb F, Blettner M. Emerging aspects of mobile phone use Emerg Health Threats J. 2009;2:e5.

20. Briem V, Hedman LR. Behavioural effects of mobile telephone use during simulated driving. Ergonomics. 1995;38:2536-2563.

21. Violanti JM. Cellular phones and fatal traffic collisions. Accid Anal Prev. 1998;30:519-524.

22. Goodman MJ, Tijerina L, Bents FD, Wierwille WW. Using cellular telephones in vehicles: safe or unsafe? Transp Hum Factors. 1999;1:3-42.

23. Beranuy M, Oberst U, Carbonell X, Chamarro A. Problematic Internet and mobile phone use and clinical symptoms in college students: the role of emotional intelligence. Comput Hum Behav. 2009;25(5): 1182-1187.

24. Lee SJ, Jin SH, Choi BJ. The Influence of Technostress and Antismart on Continuous Use of Smartphones. Proceedings of the World Congress on Engineering and Computer Science 2012. Vol I WCECS 2012. October 24-26, 2012, San Francisco, USA.

25. Brod C. Technostress: The Human Cost of the Computer Revolution. Reading, MA: Addison-Wesley; 1984.

26. King AL, Valença AM, Nardi AE. Nomophobia: the mobile phone in panic disorder with agoraphobia: reducing phobias or worsening of dependence? Cogn Behav Neurol. 2010;23(1):52-54.

27. Kuss DJ, Griffiths MD. Online social networking and addiction a review of the psychological literature. Int J Environ Res Public Health. 2011;8(9):3528-3552.

28. Choliz M. Mobile phone addiction: a point of issue. Addiction. 2010;105:373-374.

29. Potenza MN. Should addictive disorders include non-substancerelated conditions? Addiction. 2006;101:142-151.
30. Griffiths MD. Technological addictions. Clin Psychol Forum. 1995;76: 14-19.

31. Ribak R. Remote control, umbilical cord and beyond: the mobile phone as a transitional object. Br J Dev Psychol. 2009;27:183-196.

32. Kraut R, Patterson M, Lundmark V, Kiesler S, Mukophadhyay T, Scherlis W. Internet paradox: a social technology that reduces social involvement and psychological well-being? Am Psychol. 1998;53(9): 1017-1031.

33. Billieux J, Van der Linden M, Rochat L. The role of impulsivity in actual and problematic use of the mobile phone. Appl Cogn Psychol. 2008;22:9.

34. Dixit S, Shukla H, Bhagwat A, Bindal A, Goyal A, Zaidi AK, Shrivastava A. A study to evaluate mobile phone dependence among students of a medical college and associated hospital of central India. Indian J Community Med. 2010;35(2):339-341.

35. Oksman V, Turtiainen J. Mobile communication as a social stage. The meanings of mobile communication among teenagers in Finland. N Med Soc. 2004;6:319-339.

36. Krajewska-Kułak E, Kułak W, Stryzhak A, Szpakow A, Prokopowicz W, Marcinkowski JT. Problematic mobile phone using among the Polish and Belarusian University students, a comparative study. Prog Health Sci. 2012;2(1):45-50.

37. Chóliz M. Mobile Phone Addiction in Adolescence: Evaluation and Prevention of Mobile Addiction in Teenagers. Saarbrücken: Lambert Academic Publishing; 2010

38. Toda M, Monden K, Kubo K, Morimoto K. Mobile phone dependence and health-related life-style of university students. Soc Behav Pers. 2006;34:1277-1284

39. Kamibeppu K, Sugiura H. Impact of the mobile phone on junior hightschool students' friends hips in the Tokyo metropolitan area. Cyberpsychol Behav. 2005;8(2):121-130.

40. Chóliz M, Villanueva V. Questionnaire of Dependence of Mobile Phone: Psychometric Properties and Gender Differences. 11th European Congress of Psychology. Oslo; July 7-10, 2009.

41. Chóliz M, Villanueva V, Chóliz, MC. Ellas, ellos y su móvil: Uso, abuso (¿y dependencia?) del teléfono móvil en la adolescencia. [They (males and females) and their mobile: use, abuse (and addiction?) to mobile in adolescence.] Revista Española de Drogodependencias. 2009;34:74-88. Spanish.

42. Bianchi A, Phillips JG. Psychological predictors of problem mobile phone use. Cyberpsychol Behav. 2005;8:39-51.

43. Güzeller CO, Coşguner T. Development of a problematic mobile phone use scale for Turkish adolescents. Cyberpsychol Behav Soc Netw. 2012;15(4):205-211.

44. Beranuy M, Chamarro A, Graner C, Carbonell X. Validación de dos escalas breves para evaluar la Adicción a Internet y el Abuso de Móvil [Validation of two brief scales for Internet addiction and mobile phone problem use]. Psicothema. 2009;21(3):480-485. Spanish.

45. Halayem S, Nouira O, Bourgou S, Bouden A, Othman S, Halayem M. Le téléphone portable: une nouvelle addiction chez les adolescents. [Mobile Phone: a new addiction among adolescents] La Tunisie Medicale. 2010; 88:593-596. French.

46. Toda M, Monden K, Kubo K, Morimoto K. Cellular phone dependence tendency of female university students. Nihon Eiseigaku Zasshi. 2004;59:383-386. Japanese.

47. Martinotti G, Villella C, Di Thiene D, et al. Problematic mobile phone use in adolescence: a cross-sectional study. J Public Health. 2011;19: 545-551.

48. Leung L. Leisure boredom, sensation seeking, self-esteem, addiction symptoms and patterns of cell phone use. In Konijn EA, Utz S, Tanis M, Barnes SB, editors. Mediated Interpersonal Communication. Mahwah, NJ: Lawrence Erlbaum Associates; 2007:359-381.

49. Jenaro C, Flores N, Gómez-Vela M, González-Gil F, Caballo C. Problematic Internet and cell-phone use: psychological, behavioral, and health correlates. Addict Res Theory. 2007;15(3):309-320.

50. Instituto de Adicciones. Estudio de uso problemático de las tecnologías de la información, la comunicación y el juego entre los adolescentes y jóvenes de la ciudad de Madrid. [Study of pathological technology addiction among adolscents in the city of Madrid] Madrid: Madrid Salud; 2008. Spanish. 
51. Ha JH, Chin B, Park DH, Ryu SH, Yu J. Characteristics of excessive cellular phone use in Korean adolescents. Cyberpsychol Behav. 2008;11:783-784

52. Grellhesl M. Using the Uses and Gratifications Theory to Understand Gratifications Sought through Text Messaging Practices of Male and Female Undergraduate Students [PhD thesis]. TX: Texas Tech University; 2010.

53. Walsh SP, White KM, Young RM. Needing to connect: the impact of self and others on young people's involvement with their mobile phone. Aust J Psychol. 2010;62:194-203.

54. Weed NC, Butcher JN, McKenna T, Ben-Porath YS. New measures for assessing alcohol and drug abuse with the MMPI-2: the APS and the AAS. J Pers Assess. 1992;58:389-404.

55. Ezoe S, Toda M, Yoshimura K, Naritomi A, Den R, Morimoto K. Relationships of personality and lifestyle with mobile phone dependence among female nursing students. Soc Behav Pers. 2009;37(2): 231-238.

56. Black DW, Belsare G, Schlosser S. Clinical features, psychiatric comorbidity, and health-related quality of life in persons reporting compulsive computer use behavior. J Clin Psychiatry. 1999;60:839-844.

57. Hong FY, Chiu SI, Huang DH. A model of the relationship between psychological characteristics, mobile phone addiction and use of mobile phones by Taiwanese university female students. Comput Hum Behav. 2012;28(6):2152.

58. Walsh SP, White KM, Cox S, Young RM. Keeping in constant touch: The predictors of young Australians' mobile phone involvement. Comput Hum Behav. 2011;27(1):333-342.

59. Sánchez-Martínez M, Otero A. Factors associated with cell phone use in adolescents in the community of Madrid (Spain). Cyberpsychol Behav. 2009;12(2):131-137.
60. Bataller SA. Tratamiento de un caso crónico de adicción a Internet. [Treatment of a chronic case of Internet addiction] Cuadernos de Medicina Psicosomática y Psiquiatría de Enlace. 2006;79/80:71-88. Spanish.

61. Clay S, Social Software and the Politics of Groups. Networks, Economics, and Culture mailing list. March 6, 2003.

62. Marsch LA, Dallery J. Advances in the psychosocial treatment of addiction: the role of technology in the delivery of evidence-based psychosocial treatment. Psychiatr Clin North Am. 2012;35(2):481-493.

63. Free C, Knight R, Robertson S, et al. Smoking cessation support delivered via mobile phone text messaging (txt2stop): a single-blind, randomised trial. Lancet. 2011;378(9785):49-55.

64. Cadle BA, Rasmus KC, Varela JA, et al. Cellular phone-based image acquisition and quantitative ratiometric method for detecting cocaine and benzoylecgonine for biological and forensic applications. Subst Abuse. 2010;4:21-33.

65. Leena K, Tomi L, Arja RR. Intensity of mobile phone use and health compromising behaviours - how is information and communication technology connected to health-related lifestyle in adolescence? J Adolesc. 2005;28(1):35-47.

66. van Praag HM. The impact of classification on psychopharmacology and biological psychiatry. Dialogues Clin Neurosci. 1999;1(3): 141-151.

67. van Praag HM. Nosologomania: a disorder of psychiatry. World J Biol Psychiatry. 2000;1(3):151-158.

68. Ghaemi SN. Nosologomania: DSM \& Karl Jaspers' critique of Kraepelin. Philos Ethics Humanit Med. 2009;4:10.
Psychology Research and Behavior Management

\section{Publish your work in this journal}

Psychology Research and Behavior Management is an international, peerreviewed, open access journal focusing on the science of psychology and its application in behavior management to develop improved outcomes in the clinical, educational, sports and business arenas. Specific topics covered include: Neuroscience, memory \& decision making; Behavior

\section{Dovepress}

modification \& management; Clinical applications; Business \& sports performance management; Social and developmental studies; Animal studies. The manuscript management system is completely online and includes a quick and fair peer-review system. Visit http://www.dovepress. com/testimonials.php to read real quotes from published authors. 